\title{
Appraising the Performance of Chief Executive Officers of Banking Institutions in Auckland
}

\author{
Theophilus Azungah1, Adombilla Baba Blonch ${ }^{1}$, Joana Rita Tembil ${ }^{2}$ \\ ${ }^{1}$ Department of Management Studies, Bolgatanga Polytechnic, Sumbrungu, Ghana \\ ${ }^{2}$ Office of the Registrar, Bolgatanga Polytechnic, Sumbrungu, Ghana \\ Email: *babablonch@gmail.com
}

How to cite this paper: Azungah, T., Blonch, A.B. and Tembil, J.R. (2019) Appraising the Performance of Chief Executive Officers of Banking Institutions in Auckland. Open Journal of Social Sciences, 7, 478-487.

https://doi.org/10.4236/jss.2019.77038

Received: May 6, 2019

Accepted: July 28, 2019

Published: July 31, 2019

Copyright $\odot 2019$ by author(s) and Scientific Research Publishing Inc. This work is licensed under the Creative Commons Attribution International License (CC BY 4.0).

http://creativecommons.org/licenses/by/4.0/

\begin{abstract}
The financial crunch of 2008/9 occasioning the collapse of companies and financial institutions worldwide, sparked calls for transparency and accountability in the dealings of corporate bodies. It engendered more interests on issues concerning corporate governance among researchers, academicians and practitioners. It is worth noting that Chief Executive Officers (CEOs) are usually appointed and entrusted with the responsibility of managing corporate affairs on behalf of shareholders. Dual interests consequently emerge following the appointment of a CEO comprising the interest of shareholders and that of the CEO with a probability that the self-interests of CEO might run counter to the general interest of shareholders. As a result, many firms are actively incorporating into their corporate governance provisions, strategies to control executives' performance. A strategic tool used in influencing the performance of chief executives towards the desired goals of an organisation is performance appraisal, yet there is little consideration for executive appraisal in the academic literature. This study seeks to complement the dearth of scholarly conversation on executive appraisal using a qualitative single case study approach drawing on an interview with a Chief Executive Officer of an international bank based in New Zealand. Employing stakeholder theory as a theoretical lens, the findings suggest that appraising CEOs can be instrumental in building good relationships, sustain organisation's performance and enhance their career advancement.
\end{abstract}

\section{Keywords}

Chief Executive, Performance Appraisal, Bank, Board of Directors, Auckland

\section{Introduction}

Performance Management (PM) is the process that enables an organisation to 
"evaluate and improve continuously individual, subsidiary unit and corporate performance against clearly defined, pre-set objectives" [1]. Organisations are more likely to evaluate employee performance based on corporate goals and standards [2]. It is on the basis of PM that organisational resources are distributed to business units and individuals. Performance Management is instrumental for career planning and development [3] [4] since individual weaknesses and shortcomings are brought to light in the course of their work performance. Organisations are also able to draw up corrective action plans to help bridge individual performance gaps. The fundamental purpose of PM is to ensure that employees act in accordance with corporate interests [1] [5] [6].

Over the years, performance appraisal has become a prominent part of the activities of many organisations whether big or small. [6] indicated that performance appraisal is a periodic formal evaluation and rating of individuals usually by their superiors. It is a management tool for leveraging employee input into the attainment of organizational goals and objectives. Succinctly, [7] related the importance attached to performance appraisal that "everybody wants regular and detailed information on how they are doing and what the boss thinks good or bad-including executives. It's the number one thing that is going to help them grow." [7] noted that, executives performed the most unstructured, ill-defined and yet the most important function in an organisation. For this reason, it is important for their performance to be appraised and furnished with the necessary feedback.

The banking sector is the focus of this research because the sector has dominated New Zealand's financial system. The sector has also proven resilient to the financial crisis of the 2008/9 and did not require a major overhaul as experienced in other countries [8].

Despite the key importance of executive appraisal as outlined above, [7] noted that "research on appraisal abounds, yet there is little consideration of executive appraisal." Thus, there is little research on executive appraisal [7] [9]. Given the lacuna on the appraisal of executives, the focus of this paper is to seek answers to the following questions: how do chief executives of banks in Auckland perceive performance appraisal? How does performance appraisal influence their performance? Answers to these questions can help illuminate the extent to which corporate governance is exercised in the banking sector in Auckland.

\section{Literature Review}

The financial crisis of 2008/9 resulting in the collapse of companies and financial institutions worldwide ignited calls for greater transparency and accountability in the affairs of corporate bodies. The crisis of 2008/9 ignited more interest on issues concerning corporate governance. Concerns have been expressed that CEOs entrusted with the responsibility of managing corporate affairs on behalf of shareholders may tend to serve their own self-interests counter to the interests of owners. The need to devise a mechanism to measure and control the perfor- 
mance of CEOs therefore is of paramount importance [10]. Appraising the performance of CEOs is crucial for the profitability and sustainability of the banking sector because CEOs have a profound impact on the strategic direction and performance of an organisation. They act as important agents in "crafting and dispersing organizational values and visions to both organization members and the external environment" [11]. As a result, many firms are making strenuous efforts to incorporate into their corporate governance provisions, strategies to control executives' behaviour [10] [12].

A strategic tool used in influencing the behaviour of chief executives towards the desired goals of an organisation is performance appraisal. Performance appraisal is an essential part of the board of directors' governance roles. In appraising a chief executive, the board of directors of a company usually set up a committee that meets with the chief executive to discuss achievements and challenges, areas of concern, salary and benefits issues, goals and plans for the next appraisal period [13].

[14] asserted that companies that practised executive appraisal experienced positive outcomes such as greater accountability for performance as a result of formal mutually agreed targets put in place jointly by board and executive. Strategic goals are usually clarified at the beginning of each year with quantifiable measures that enabled chief executives to have clearer focus. The strategic focus cascades down to multiple layers in an organisation and thereby reinforcing the strategic direction of organisational members. Executive evaluation promotes healthy relations between the $\mathrm{CEO}$ and the board and also provides feedback to a CEO on areas that need to be improved upon or new skills that may be needed as a source of leadership development for the CEO. Thus the overall benefit of a properly administered executive appraisal serves to benefit the board, the CEO and an entire organisation. A CEO gets constructive feedback from the board on his or her performance and the board is also in a position to assess the extent to which organisational goals have been achieved.

There is no universal theoretical approach for performance appraisal for CEOs in modern organisations. [15] explained CEOs performance appraisal under the following dimensions: leadership, strategy, people management, financial returns and relationship with stakeholders. [16], writing on appraisal of CEOs of hospitals, noted that appraisals usually centred on finance, executive team development, organizational culture, strategic planning and relationships with the board.

[12] categorised executive appraisal into two namely the agency and stakeholder perspectives. Agency theory seeks shareholders' interest and wealth maximisation in the decision making process while that of stakeholder theory takes into account the interest of multiple stakeholders such as employees, suppliers, creditors and community. Agency approach is based on the premise that shareholders provide the capital for wealth creation and are therefore more vulnerable to risk. Performance measurement of the chief executive according to the agency theory should be based on financial measures while that of the 
stakeholder theory is based on financial and non-financial measures. Non-financial measures are equally important as some scholars have argued that certain CEO behaviours are crucial for the motivation, building good relationships with employees as well as enhancing employee well-being [17]. CEO behaviours that may be deemed toxic can negatively impact the "longevity of an executive's performance" [18]. For, it is in building constructive and positive relationships with others that a CEO can sustain performance. Governance in the agency perspective is based on control and compliance while that of the stakeholder is based on coordination, cooperation and conflict resolution.

This research focuses on stakeholder theory because the theory incorporates a broader picture. [19] note that non-financial performance measures have incremental information about the performance of CEOs because they include performance dimensions not fully captured in financial measures such as customer satisfaction. Thus executive performance should not only be assessed in terms of financial measures which tend to be narrow in focus but also on non-financial measures such as employee welfare, social responsibility, relationships with suppliers, creditors etc. In combining financial and non-financial measures in appraising the executive, a much more holistic picture of the CEO, the organisation and its community are taken into consideration.

[13] suggest a number of steps to be followed when conducting an executive appraisal. First of all, the board sets an ad hoc committee comprising members drawn from the board. The committee is given a clear mandate with well-defined guidelines, responsibilities and a time frame to submit its report. The Chairman of the board usually works with the appraisal committee to plan the process and also to provide the committee with any external assessment of the CEO that may be needed. Information that is usually needed by the committee for its work includes:

1) the organisation's current strategic plan,

2) the CEO's job description,

3) the CEO's regular and annual reports to the board,

4) annual goals with action plans,

5) external feedback or list of people that the committee can interview to gather external feedback on aspects of the CEO's work.

The committee then sets dates and agenda for the appraisal after which it writes its report. From the foregoing, it may be noted that organisations adopt various approaches in appraising their CEOs but for the purposes of this research, the stakeholder perspective is deemed appropriate to answer effectively how executive appraisal affects executives' performance. The stakeholder approach is suitable because of its broad scope by focusing on both financial and non-financial performance measures such as innovation, quality, competitive performance, resource utilisation and flexibility.

\section{Methodology}

In order to draw closer to experience the world of CEOs, interpret and under- 
stand their behaviour a qualitative case study research was conducted to elicit the desired information. A case study offers a holistic view and understanding of social phenomena [20] [21] [22]. Also, a case study offers rich accounts of organisational practices and in-depth understanding of actors and their worlds. [23] notes that a case study is appropriate for examining "contemporary phenomenon within its real-life context, especially when the boundaries between the phenomenon and context are not clearly evident". This definition of case study can aptly be applied to the context of CEOs working in the banking sector in New Zealand. Executive appraisal is a contemporary phenomenon that is indistinguishable with its context, the banking sector. Chief Executives' appraisal can only be understood in their role settings and natural context in terms of how they relate with employees, board members, client relationships and compliance with regulations. A case study makes it possible to explore complex situations from a range of sources of information [24] [25] such as company brochures, newspaper publications, observations, memoranda and other archival documents. However, for purposes of this study, observations, company brochures, newspaper publications and archival documents were utilised alongside semi-structured interviews. Purposive sampling was used in this research as a sampling strategy. Chief Executive Officers of banks in Auckland constitute the key informants for this study since they are in a position to give detailed information and responses to the research questions. The first author was responsible for collecting the data in New Zealand. The preferred venue for the interview was the manager's office in order to capture the lived experience characterised by that "naturalness and role voice". We assigned pseudo names to the respondent and the bank to ensure anonymity and confidentiality. The researcher interviewed a middle-aged manager of ZENO International Bank. The interviews were tape-recorded to ensure an accurate account of the conversation and to avoid missing any part of the data [26]. [25] note that recording and transcribing interviews allows thorough examination of what people say and permits repeated examination of the interviewee's answers. The interview took place in the participant's office at his own convenience. It lasted for about 35 minutes. I thanked the respondent again for his time and courtesies extended to me.

Interview transcripts were entered as text files to NVivo software version 11 for coding. Key concepts and themes were identified using the research questions as lenses. The narratives are organised around themes such as job role, key performance indicators, financial and non-financial measures and the importance of CEO appraisal. We collected data from multiple sources observations, documents and the interview which served to enhance the credibility and trustworthiness of the research claims [25].

\section{Presentation and Discussion of Findings}

The narratives are organised around themes such as job role, key performance indicators, financial and non-financial measures, and usefulness of CEO ap- 
praisal and the effect of performance appraisal on performance. The manager plays an advisory role to the bank with regards to lending to credit worthy customers and to conducting banking businesses in accordance with government legal requirements e.g. not lending credit for money laundering purposes and other fraudulent activities.

In response to the question relating to his job role, the manager explained that "in my present role, I am a leader by example, caring for my employees, allowing them to enjoy their full holidays, health care benefits and nurturing good working relationships with all of them". The CEO's relationship-building behaviours are critical for the prolonged existence of their success within an organisation.

In response to a query about the importance of executive appraisal, the manager minced no words when he emphatically stated "no one can 'cruise' along unchecked at this level in any corporate environment. Appraisals are linked to personal development plans and key performance indicators are a key part of employee engagement". Thus he likened the executive's job to a journey where one is "policed or checked to ensure that corporate regulations are complied with". This is further buttressed by the fact that there is a duality of interests emanating from the $\mathrm{CEO}$ and shareholders with a probability that the self-interests of CEOs might run counter to the general interest of shareholders. As a result, many firms are making strenuous efforts to incorporate into their corporate governance provisions, strategies to control executives' behaviour [10].

Contrary to our belief that the appraisal process is usually filled with excitement, the manager explained that it was a combination of excitement and nervousness. He explained it is a period filled with anxiety, nervousness and sometimes excitement. One may become sleepless sometimes, and eagerly waiting to get over the appraisal process. We were a bit surprised because we least expected personnel at this level of corporate affairs to feel nervous about appraisal.

The manager explained that financial measures form a key component of executive appraisal and they include "revenues, return on investment, profit margin". Taking an accounting perspective to executive performance measurement is particularly important when linking performance to remuneration; while non-financial measures are "brand recognition, customer satisfaction, client relationships, employee and customer satisfaction" which are equally crucial in building fruitful relations with employees, enhancing employee well-being and sustaining performance [18]. The appraisal in this instance, parallels with the stakeholders' perspective that takes into account the interest of multiple stakeholders [12] [19]. According to the manager, "personal goals jointly established with the board were regarded as key performance indicators". He notes further that the appraisal process at certain times "becomes less formal and held at a café over coffee". The joint establishment of goals between the board and the manager is in consonance with what [14] finding that companies that practise executive appraisal experience positive outcomes such as greater accountability for per- 
formance as a result of formal mutually agreed targets put in place jointly by board and executive.

In answer to a question as to how performance appraisal affected his subsequent performance, the manager noted that "they (performance appraisals) are linked directly to bonus structures. So therefore, you set your goals and try to exceed expectations". In appraising a chief executive, the board of directors of a company usually set up a committee that meets with the chief executive to discuss a range of issues including achievements and challenges, salary and benefits issues and plans for the next appraisal period [13]. CEO appraisals may therefore be directly linked to motivation and commitment to one's job. The Chief executive might see the board's efforts in discussing areas of concern and deciding on salary and other benefits as a genuine desire for him to succeed.

\section{Conclusions and Implications for Theory and Practice}

The research findings suggest that executive appraisal is an important part of the corporate governance process and provide a board with the crucial indicators of a CEO's characteristics and quality. The research also finds out that many executives want performance appraisals that will help inform them as to whether they are on the right path or not. Thus, CEO appraisal helps promote objectivity about CEO remuneration, accountability and transparency in the operation of an enterprise, provide early warning signals for problems and encourage CEO's career development. The importance of financial and non-financial performance measures in appraising CEOs cannot be overemphasized as they complement each other in giving incremental information about the organization.

There is a dearth of research literature that employed a qualitative case study methodology to research executive appraisal particularly within the banking sector. Some scholars have also expressed concern about the over-reliance on quantitative methods for International Business (IB) research [27] [28] [29]. This paper utilises a qualitative approach of inquiry as a contribution towards filling this "methodological gap generated by the heavy reliance on quantitative methods" [27]. In so doing, this research extends the methodological literature on case studies in IB by combining context sensitivity and rigorous explanations into how chief executives perceive performance appraisal. Findings from this study may help corporate boards particularly in the banking sector to incorporate and implement executive appraisal in their various organisations in order to minimise fraud, improve employee motivation and to achieve corporate strategic goals.

\section{Limitations and Directions for Further Research}

The key limitation of this study is that the findings are based on the responses of a single person. Secondly, the organisational literature in the form of brochures, newspaper publications that serve to make the findings of a case study robust could not be accessed due to reasons of business confidentiality. The study relied 
on only the semi-structured interview, memo and observations. The respondent was very terse and parsimonious in his responses since according to him they were not allowed to communicate on any topic concerning the bank to an outsider without explicit consent from the board and their legal team. As a result, the in-depth description of the phenomenon studied is limited. Future research should consider exploring more avenues to access more organisations in order to broaden the scope of data and the findings. While the qualitative case study provided in-depth knowledge on executive appraisal, adopting an ethnographic approach could probably yield greater insights into the appraisal and might provide a more nuanced understanding of the stakeholders' perception of CEOs' performance.

\section{Acknowledgements}

We acknowledge the constructive suggestions provided by Dr. Michael Haule.

\section{Conflicts of Interest}

The authors declare no conflicts of interest regarding the publication of this paper.

\section{References}

[1] Shen, J. (2005) Effective International Performance Appraisals: Easily Said, Hard to Do. Compensation and Benefits Review, 37, 70-79. https://doi.org/10.1177/0886368705277656

[2] Cascio, W.F. (2012) Global Performance Management Systems. In: Stahl, G., Björkman, I. and Morris, S., Eds., Handbook of Research in International Human Resource Management, Edward Elgar, Cheltenham, 176-198.

[3] Aguinis, H. (2013) Performance Management. Prentice Hall, Upper Saddle River.

[4] Alimo-Metcalfe, B. (1993) Women in Management: Organisational Socialisation and Assessment Practices That Prevent Career Advancement. International Journal of Selection and Assessment, 1, 68-83. https://doi.org/10.1111/j.1468-2389.1993.tb00091.x

[5] Evans, P., Pucik, V. and Björkman, I. (2011) Global Performance Management. In: Evans, P., Pucik, V. and Björkman, I., Eds., The Global Challenge: International Human Resource Management, McGraw-Hill, New York, 346-390.

[6] Armstrong, M. (2009) Armstrong's Handbook of Performance Management: An Evidence-Based Guide to Delivering High Performance. Kogan Page, Philadelphia.

[7] Longenecker, C.O. and Gioia, D.A. (1992) The Executive Appraisal Paradox. The Executive, 6, 18-28. https://doi.org/10.5465/ame.1992.4274393

[8] Bollard, A., Hunt, C. and Hodgetts, B. (2011) The Role of Banks in the Economy-Improving the Performance of the New Zealand Banking System after the Global Financial Crisis. The New Zealand Shareholders Association Annual Meeting, Tauranga, Vol. 6.

[9] Anderson, B. and Kleiner, B.H. (2003) How to Evaluate the Performance of Chief Executive Officers Effectively. Management Research News, 26, 3-11. https://doi.org/10.1108/01409170310783736 
[10] Cole, C.R., He, E., McCullough, K.A., Semykina, A. and Sommer, D.W. (2011) An Empirical Examination of Stakeholder Groups as Monitoring Sources in Corporate Governance. Journal of Risk and Insurance, 78, 703-730. https://doi.org/10.1111/j.1539-6975.2011.01428.x

[11] Gentile-Lüdecke, S., Halaszovich, T. and Lundan, S. (2019) What Role Does CEO Vision Play in the Internationalization Process of Firms? Evidence from the Banking Sector in Africa. Thunderbird International Business Review, 61, 13-27. https://doi.org/10.1002/tie.21958

[12] Abdalla, R.M., Saleh, A., Kumar, N. and Ann, J.H. (2012) The Evaluation of Chief Executive Officer Performance: A Stakeholder Theory Perspective. World Journal of Social Science, 2, 121-137.

[13] Heather, H. and Joan Heys, H. (2008) Hiring and Performance Appraisal of the Executive Director: A Self-Guided Book. Muttart Foundation, Edmonton.

[14] Conger, J.A., Finegold, D. and Lawler, E.E. (1998) Appraising Boardroom Performance. Harvard Business Review, 76, 136-164.

[15] Kaufman, S.P. (2008) Evaluating the CEO. Harvard Business Review, 86, 53-57.

[16] Schleeter, D. (2011) The Essential CEO Appraisal. Trustee: The Journal for Hospital Governing Boards, 64, 6.

[17] Pereira, R., Boles, J., Vieira, V.A., Johnson-Busbin, J. and Barksdale, H. (2018) Unpacking the Account Executive Performance, Its Antecedents, and Relational Outcomes: An Abstract. In: Krey, N. and Rossi, P., Eds., Boundary Blurred: A Seamless Customer Experience in Virtual and Real Spaces. AMSAC 2018. Developments in Marketing Science: Proceedings of the Academy of Marketing Science, Springer, Cham, 379-380. https://doi.org/10.1007/978-3-319-99181-8_119

[18] Hutchison, A. and Burch, G.S.J. (2011) Senior-Executive Performance: Interrater Reliability and Rater Effects in Multi-Source Ratings. Asia Pacific Journal of Human Resources, 49, 425-439. https://doi.org/10.1177/1038411111423187

[19] Davila, A. and Venkatachalam, M. (2004) The Relevance of Non-Financial Performance Measures for CEO Compensation: Evidence from the Airline Industry. Review of Accounting Studies, 9, 443-464. https://doi.org/10.1007/s11142-004-7792-8

[20] Gummesson, E. (1991) Qualitative Methods in Management Research. Sage, Thousand Oaks.

[21] Yin, R.K. (1984) Case Study Research: Design and Methods (Vol. 5). Sage Publications, Thousand Oaks.

[22] Parker, L.D. (2003) Qualitative Research in Accounting and Management: The Emerging Agenda. Journal of Accounting and Finance, 2, 15-39.

[23] Yin, R.K. (2003) Case Study Research: Design and Methods. 3rd Edition, Sage, Thousand Oaks.

[24] Lauckner, H., Paterson, M. and Krupa, T. (2012) Using Constructivist Case Study Methodology to Understand Community Development Processes: Proposed Methodological Questions to Guide the Research Process. The Qualitative Report, 17, $1-22$.

[25] Bryman, A. and Bell, E. (2015) Business Research Methods. Oxford University Press, Oxfordd.

[26] Noor, K.B.M. (2008) Case Study: A Strategic Research Methodology. American Journal of Applied Sciences, 5, 1602-1604.

https://doi.org/10.3844/ajassp.2008.1602.1604 
[27] Cooke, F.L. (2009) A Decade of Transformation of HRM in China: A Review of Literature and Suggestions for Future Studies. Asia Pacific Journal of Human Resources, 47, 6-40. https://doi.org/10.1177/1038411108099288

[28] Meyer, K.E. (2006) Asian Management Research Needs More Self-Confidence. Asia Pacific Journal of Management, 23, 119-137.

https://doi.org/10.1007/s10490-006-7160-2

[29] Marschan-Piekkari, R. and Welch, C. (2004) Qualitative Research Methods in International Business: The State of the Art. In: Marschan-Piekkari, R. and Welch, C., Eds., Handbook of Qualitative Research Methods for International Business, Edward Elgar, Cheltenham, 5-24. https://doi.org/10.4337/9781781954331 